\title{
Bile Acid Regulates the Colonization and Dissemination of Candida albicans from the Gastrointestinal Tract by Controlling Host Defense System and Microbiota
}

\author{
Shankar Thangamani ${ }^{1,2,3, *}$, Ross Monasky ${ }^{3}$, Jung Keun Lee ${ }^{3}$, Vijay Antharam ${ }^{4}$, Harm HogenEsch ${ }^{1,2}$, \\ Tony R. Hazbun ${ }^{5}$, Yan Jin ${ }^{6}$, Haiwei Gu ${ }^{6,7}$ and Grace L. Guo ${ }^{8,9}$ \\ Citation: Thangamani, S.; Monasky, \\ R.; Lee, J.K.; Antharam, V.; \\ HogenEsch, H.; Hazbun, T.R.; Jin, Y.; \\ Gu, H.; Guo, G.L. Bile Acid Regulates \\ 1 Department of Comparative Pathobiology, College of Veterinary Medicine, Purdue University, \\ West Lafayette, IN 47906, USA; hogenesc@purdue.edu \\ 2 Purdue Institute for Immunology, Inflammation and Infectious Diseases (PI4D), \\ West Lafayette, IN 47906, USA \\ 3 College of Veterinary Medicine, Midwestern University, Glendale, AZ 85308, USA; \\ rmonas@midwestern.edu (R.M.); jlee2@midwestern.edu (J.K.L.) \\ 4 Department of Chemistry, College of Arts, Humanities and Sciences, Methodist University, \\ Fayetteville, NC 28311, USA; vantharam@methodist.edu \\ 5 Department of Medicinal Chemistry and Molecular Pharmacology, College of Pharmacy, Purdue University, \\ West Lafayette, IN 47906, USA; thazbun@purdue.edu \\ 6 Arizona Metabolomics Laboratory, College of Health Solutions, Arizona State University, \\ Phoenix, AZ 85004, USA; kimyeon909@gmail.com (Y.J.); hgu@fiu.edu (H.G.) \\ 7 Center for Translational Science, Department of Environmental Health Sciences, Robert Stempel College of \\ Public Health and Social Work, Florida International University, Port St. Lucie, FL 33199, USA \\ 8 Department of Pharmacology and Toxicology, Earnest Mario School of Pharmacy, Rutgers University, \\ Piscataway, NJ 08854, USA; glg48@eohsi.rutgers.edu \\ 9 Department of Veterans Affairs New Jersey Health Care System, East Orange, NJ 07018, USA \\ * Correspondence: sthangam@purdue.edu; Tel.: +1-765-494-0763
} the Colonization and Dissemination of Candida albicans from the Gastrointestinal Tract by Controlling Host Defense System and Microbiota. J. Fungi 2021, 7, 1030. https:// doi.org/10.3390/jof7121030

Academic Editor:

Jennifer Geddes-McAlister

Received: 1 November 2021

Accepted: 24 November 2021

Published: 30 November 2021

Publisher's Note: MDPI stays neutral with regard to jurisdictional claims in published maps and institutional affiliations.

Copyright: (c) 2021 by the authors Licensee MDPI, Basel, Switzerland. This article is an open access article distributed under the terms and conditions of the Creative Commons Attribution (CC BY) license (https:/ creativecommons.org/licenses/by/ $4.0 /)$
Abstract: Candida albicans (CA), a commensal and opportunistic eukaryotic organism, frequently inhabits the gastrointestinal (GI) tract and causes life-threatening infections. Antibiotic-induced gut dysbiosis is a major risk factor for increased CA colonization and dissemination from the GI tract. We identified a significant increase of taurocholic acid (TCA), a major bile acid in antibiotictreated mice susceptible to CA infection. In vivo findings indicate that administration of TCA through drinking water is sufficient to induce colonization and dissemination of CA in wild-type and immunosuppressed mice. Treatment with TCA significantly reduced mRNA expression of immune genes ang 4 and Cxcr3 in the colon. In addition, TCA significantly decreased the relative abundance of three culturable species of commensal bacteria, Turicibacter sanguinis, Lactobacillus johnsonii, and Clostridium celatum, in both cecal contents and mucosal scrapings from the colon. Taken together, our results indicate that TCA promotes fungal colonization and dissemination of CA from the GI tract by controlling the host defense system and intestinal microbiota that play a critical role in regulating CA in the intestine.

Keywords: bile acid metabolites; fungal colonization and dissemination; microbiota; host defense system

\section{Introduction}

Candida albicans (CA), a commensal and opportunistic eukaryotic organism, frequently inhabits the gastrointestinal (GI) tract and can cause life-threatening infections [1-4]. CA is present in small numbers in the healthy GI tract of humans; thus, CA is harmless in immunocompetent humans [5,6]. While dysregulation in the host defense system contributes to invasive CA infections, the use of broad-spectrum antibiotics is a major predisposing risk factor for increased fungal colonization, and subsequent dissemination from the intestine [7-14]. CA is normally absent in the GI tract of adult mice; however, 
antibiotic treatment leads to CA colonization and dissemination in mice, and closely resembles CA infection in human patients [5,6,14-22]. Because colonization of the GI tract is necessary for the dissemination of CA, and CA colonization resistance is nullified by antibiotic treatment, identifying the factors that play a critical role in CA colonization may pave the way to develop novel approaches to limit CA dissemination $[6,20]$.

Antibiotics alter the intestinal microbiota and lead to changes in the composition of the gut microbial metabolites that play a critical role in controlling several enteric bacterial pathogens [23-25]. However, there is limited knowledge about the potential role of microbial metabolites in the regulation of CA colonization and pathogenesis. To address this knowledge gap, we previously performed targeted metabolomics, and identified several groups of metabolites that are differentially regulated in the gut contents of cefoperazone-treated CA-susceptible mice and control CA-resistant mice [26]. A bile acid, taurocholic acid (TCA), was identified as one of the major classes of metabolites that was considerably increased in the antibiotic-treated mice [26]. Following synthesis in the liver, TCA enters the intestine and undergoes two major chemical modifications (deconjugation and dihydroxylation) carried out by gut microbes [27-29]. Antibiotic treatment depletes TCA-metabolizing commensal bacteria, leading to increased levels of TCA in the gut contents [26]. Furthermore, the gut concentration of TCA is considerably altered in different diseases. Specifically, TCA is highly up-regulated in immunocompromised cancer patients [30-32], drug-induced liver injury [33-35], high-fat diets [36], and liver cirrhosis [37-42], conditions that are associated with severe morbidity and mortality caused by CA. Numerous FDA-approved drugs and probiotics currently used to treat various diseases also profoundly alter bile acid levels, including TCA in the gut [43-52]. Therefore, understanding the role of TCA in the regulation of CA will gain insights into the bilemediated regulation of gut fungi, and will form a platform to develop novel therapies to control and treat invasive CA infections that arise as a result of antibiotic-induced dysbiosis, and to control CA-associated infections in individuals with liver cirrhosis. Therefore, in this study, we investigated the role of TCA on CA colonization and dissemination from the intestine. Our findings indicate that TCA promotes fungal colonization and dissemination by altering the intestinal defense system and microbiota.

\section{Materials and Methods}

\subsection{Strains and Reagents}

Candida albicans SC5314 was provided by Dr. Andrew Koh at the University of Texas Southwestern Medical Center [6]. This study used Yeast Peptone Dextrose (YPD) (242810, BD Difco, Franklin Lakes, NJ, USA) agar (BP1423, Fisher, Waltham, MA, USA), as well as Bacteroides Bile Esculin Agar (BBE) (AS114, Anaerobe Systems, Morgan Hill, CA, USA) for various assays. Additionally, the antibiotics kanamycin (J61272, Alfa Aesar, Tewsbury, MA, USA), ampicillin (69-52-3, IBI Scientific, Dubuque, IA, USA), and streptomycin (S6501, Sigma-Aldrich, St. Louis, MO, USA) were used in media for fungal enumeration, and cefoperazone (J65185, Alfa Aesar, Tewsbury, MA, USA) was used in antibiotic pre-treatment. Taurocholic acid (TCA) (16215, Cayman Chemicals, Ann Arbor, MI) and cyclophosphamide (PHR1404, Millipore Sigma, St. Louis, MO, USA) were purchased for these studies. Additional kits and reagents used included: hydrogen sulfide gas assay (ZAN-5084, Cell Biolabs, San Diego, CA), fluorescein isothiocyanate-dextran (FITC-dextran) (FD4, Millipore Sigma, St. Louis, MO, USA), and sodium formate (A17813, Alfa Aesar).

\subsection{Fungal Colonization and Dissemination in the Immunosuppressed Mouse Model}

Studies specifically examining survival and dissemination of mice infected with C. albicans SC5314 under immunosuppressive conditions were performed with BALB/c mice. Male and female mice (age 8 to 12 weeks old) were treated with or without cefoperazone $(0.5 \mathrm{mg} / \mathrm{mL})$ via drinking water, and drinking water was replaced with fresh antibiotic water every two days. After 7 days, all mice were infected with Candida albicans SC5314 via oral gavage with $1-2 \times 10^{8} \mathrm{CFU} /$ mouse. Three days post-infection, all mice 
were treated with $150 \mathrm{mg}$ of cyclophosphamide (cyclo) per kilogram of mouse body weight by intraperitoneal injection. A second and third dose of cyclophosphamide was given at 5- and 7-days post-infection, respectively. Mice were monitored for survival, and euthanized if mice were moribund. After euthanasia, cecal contents, liver, and kidneys were collected and processed for fungal burden to assess the fungal dissemination as described before [26]. Briefly, gut contents and tissue homogenates were serially diluted and plated onto YPD agar plates containing broad-spectrum antibiotics, and incubated at $30^{\circ} \mathrm{C}$ for $24 \mathrm{~h}$ to determine the colony-forming units (CFU).

\subsection{Effect of TCA on Fungal Colonization and Dissemination in Mice}

Male and female wild-type C57B/6 mice were infected with C. albicans SC5314 via oral gavage with 1-2 × $10^{8} \mathrm{CFU} /$ mouse. One group of mice was treated with $1 \%$ TCA in the drinking water, and the water was changed every day. Control groups received sterile water. Fecal contents were collected at the indicated time points to determine the fungal load in feces. Mice were monitored for survival, and cecal contents, liver, and kidneys were processed to determine the fungal load and dissemination as described before [26]. To determine the effect of TCA on fungal colonization and dissemination in the immunosuppressed mouse model, male and female BALB/cJ mice (age 10 to 12 weeks old) were infected as described above, and all mice were treated with $150 \mathrm{mg}$ of cyclophosphamide (cyclo) per kilogram of mouse body weight through intraperitoneal injection. The second and third doses of cyclophosphamide were given again at 5- and 7-days post-infection, respectively.

\subsection{FITC-Dextran Permeability Assay}

Gut permeability was measured in infected mice using a FITC-dextran assay. Wild type C57BL/6 mice were infected with Candida albicans SC5314 via oral gavage with $1-2 \times 10^{8} \mathrm{CFU} /$ mouse, and treated with or without $1 \%$ TCA through drinking water. After 10 days post-infection, mice were orally administered $150 \mathrm{uL}$ PBS containing $15 \mathrm{mg}$ FITC-dextran. The mice were anesthetized four hours later, and blood was collected via retro-orbital route. Blood samples were then centrifuged to collect serum. Serum samples were processed via a 2-fold serial dilution in a 96-well plate, and fluorescence was measured via plate reader (excitation: $485 \mathrm{~nm}$; emission: $520 \mathrm{~nm}$ ). Standard curves were made using serially diluted FITC-Dextran in PBS to determine the FITC-Dextran levels in serum samples.

\subsection{RNA Sequencing and Analysis}

Wild type C57BL/ 6 mice were infected with C. albicans SC5314 via oral gavage with $1-2 \times 10^{8} \mathrm{CFU} /$ mouse, and treated with or without $1 \%$ TCA through drinking water. At 10 days post-infection, the colon was collected and flash-frozen in liquid nitrogen. Total RNA was collected using a Zymo Research RNA kit as per the manufacturer's instructions. Total RNA-Seq libraries were constructed from $500 \mathrm{ng}$ of total RNA, and rRNA was removed. Libraries were prepared using the Zymo-Seq RiboFree Total RNA Library Prep Kit (Cat \# R3000) according to the manufacturer's instructions. RNA-Seq libraries were sequenced on an Illumina NovaSeq to a sequencing depth of at least 30 million read pairs (150 bp paired-end sequencing) per sample. Sequence data alignments and differential expression analysis: NovaSeq paired-end 150-bp reads from Total RNA-Seq data files were first adaptor-trimmed, and then analyzed using the STAR program (version 2.6.1d) for alignment of short reads to the genome of interest. Transcript counts were inferred from alignment files. All transcripts with either 0 or 1 counts were removed. Gene expression was measured using EdgeR. The DESeq2 R package was used for differential expression analysis using the gene feature.

\subsection{Microbiome Sequencing and Analysis}

Wild type C57BL/6 mice were infected with C. albicans SC5314 via oral gavage with 1-2 $\times 10^{8} \mathrm{CFU} /$ mouse, and treated with or without $1 \%$ TCA through drinking water. After 
10 days post-infection, cecal contents and mucosal scrapings from the colon were collected using glass slides to determine the microbiome composition. Microbiome sequencing was carried out at Zymo Research corporation (Irvine, CA, USA). The ZymoBIOMICS ${ }^{\circledR}$ Microbial Community Standard (Zymo Research, Irvine, CA, USA) was used as a positive control for each DNA extraction, if performed. The final library was sequenced on Illumina ${ }^{\circledR}$ MiSeqTM with a v3 reagent kit (600 cycles), and the relative abundance of bacteria was analyzed as described elsewhere [26].

\subsection{Immunofluorescence Staining}

The colon from untreated and TCA-treated mice infected with CA were collected after 10-12 days of infection. Colon tissue was fixed in 10\% neutral buffered formalin solution, sectioned at $5 \mu \mathrm{m}$, and stained with DAPI and ZO-1 Antibody (21773-1-AP, Thermofischer, Waltham, MA, USA). Stained tissues were imaged (40X) using a Keyence BZ-X700 microscope.

\subsection{Metabolomics}

Bile acid metabolites (TCA and DCA) levels in the cecal contents were determined as described previously [26].

\subsection{Statistical Analysis}

Statistical analyses were performed using GraphPad Prism 6.0 (Graph Pad Software, La Jolla, CA). $p$ values were calculated using the Mann-Whitney $U$ test or unpaired Student's $t$-test, or by one way-ANOVA followed by a Bonferroni comparison or KaplanMeier (log-rank) survival test as indicated. $p$ values of $\left({ }^{*} \leq 0.05\right),\left({ }^{* *} p \leq 0.01\right),\left({ }^{* * *} p \leq 0.001\right)$, and $(* * * p \leq 0.0001)$ were considered as significant.

\section{Results}

\subsection{TCA Is the Major Bile Acid Metabolite Up-Regulated in the Cefoperazone-Treated Mice} Susceptible to CA Infection

To identify the metabolites that regulate CA colonization and dissemination, we treated BALB/c mice with or without a broad-spectrum antibiotic (cefoperazone), orally infected them with CA, and then injected them with cyclophosphamide intraperitoneally. As expected, all mice in the antibiotic-treated group died within 6 days of infection (Figure 1A). Furthermore, the fungal load was significantly higher in the cecal contents and liver of antibiotic-treated mice, thus, confirming increased CA colonization and dissemination from the GI tract of antibiotic-treated mice compared to control groups (Figure 1B). Previous findings from our lab indicate that more than 200 metabolites were differentially regulated in the cecal contents of control and antibiotic-treated mice [26]. Bile acids are one of the major metabolites differentially altered in the CA-susceptible mice compared to control groups [26]. Reanalysis of our previously published metabolomics data set indicates that six bile acids were significantly up-regulated in the antibiotic-treated CA susceptible mice (Figure 1C,D) [26]. Interestingly, only the abundance of TCA was significantly higher than all other bile acid metabolites that were increased in the antibiotic-treated CA susceptible mice compared to untreated control groups (Figure 1D). These results indicate that TCA is the highly up-regulated bile acid in the antibiotic-treated CA-susceptible mice compared to control groups. 
(A)

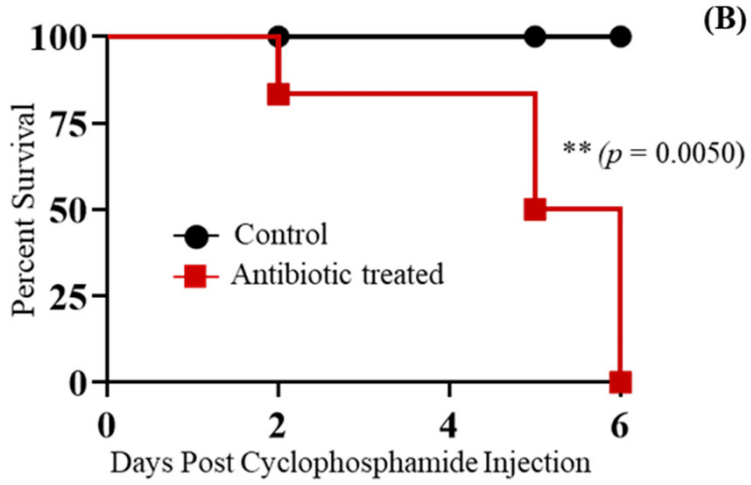

(C)

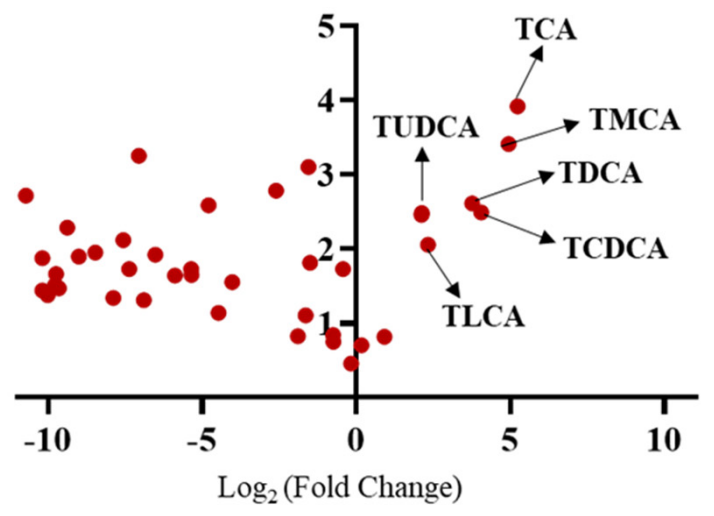

(B)

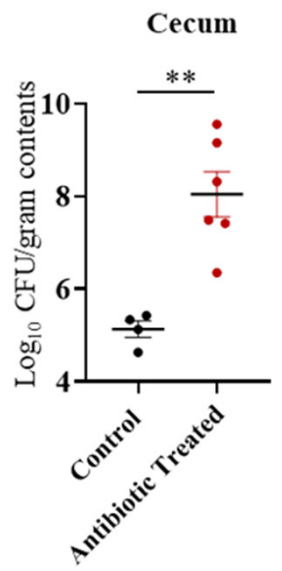

Liver Kidney

(D)
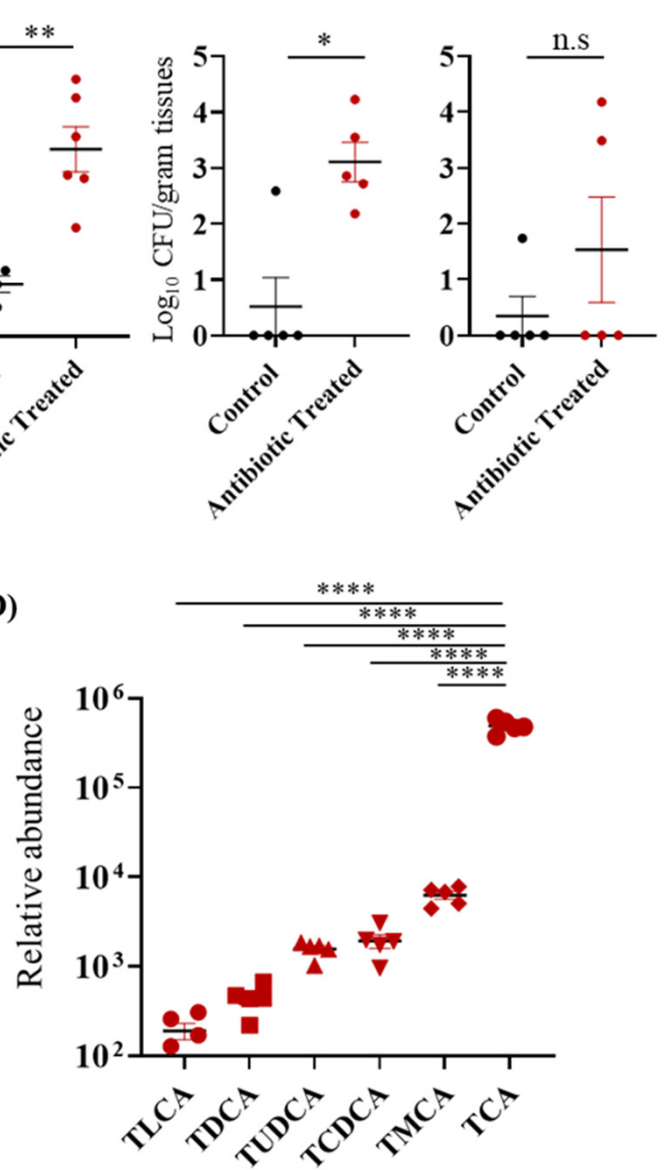

Figure 1. Taurocholic acid (TCA) is the major bile acid metabolite up-regulated in the cefoperazone-treated mice susceptible to CA infection. (A) BALB/c mice were fed sterile water in the presence or absence of cefoperazone $(0.5 \mathrm{mg} / \mathrm{mL})$ for 7 days and then infected with $\sim 2 \times 10^{8}$ CFU CA SC5314 via oral gavage. Antibiotic treatment was continued until the end of the experiment. Three days post-infection, all mice were injected with three doses of cyclophosphamide intraperitoneally ( $150 \mathrm{mg} / \mathrm{kg}$ body weight) and monitored for survival. A log-rank test was performed using $95 \%$ confidence intervals; statistical significance was calculated to compare the antibiotic-treated and untreated control groups. (B) Fungal load from cecum, liver, and kidney were collected immediately after death in the antibiotic-treated groups and mice euthanized after 6 days post-cyclophosphamide treatment from control groups. Statistical significance was evaluated using the Mann-Whitney $\mathrm{U}$ test. (C) Relative $\log _{2}$ fold-change of bile acid metabolites in antibiotic-treated C57BL/ 6 mice relative to control groups. (D) Relative abundance of bile acid metabolites that were highly up-regulated and significant in the antibiotic-treated group relative to control groups. At least five mice per group were used, and the data represents mean \pm SEM. one way-ANOVA followed by a multiple comparison using Bonferroni correction. $p$ values of $(* p \leq 0.05),(* * p \leq 0.01)$, and $(* * * * p \leq 0.0001)$ were considered as significant.

3.2. TCA Alone Induces Fungal Colonization and Dissemination from the GI Tract in the Absence of Antibiotics and Immunosuppressive Agents

To dissect the specific role of TCA in regulating CA colonization and dissemination in vivo, C57BL/6 J mice infected with CA were treated orally with or without $1 \%$ TCA in the drinking water (Figure 2A). The fungal load in stool samples, and mortality were monitored. Mice treated with TCA alone died 15 days post-infection (Figure 2B). 
(A)

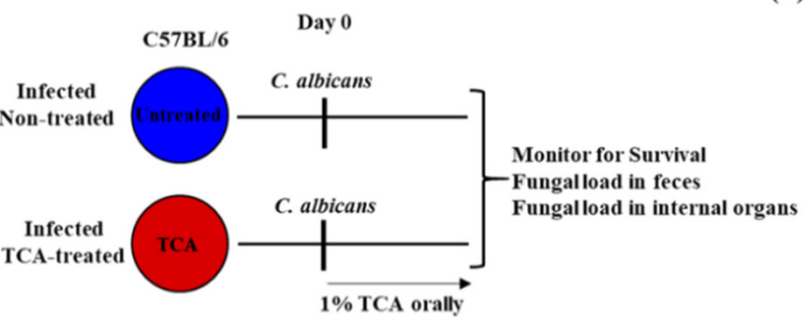

(B)

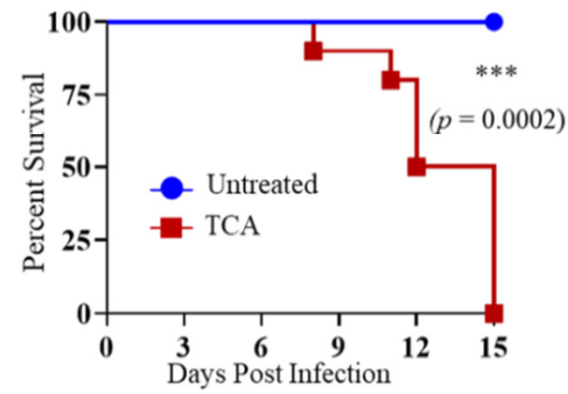

(D)
(C)
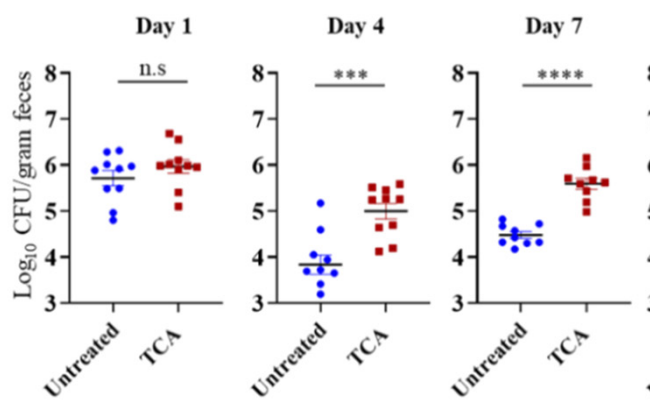

Day 12
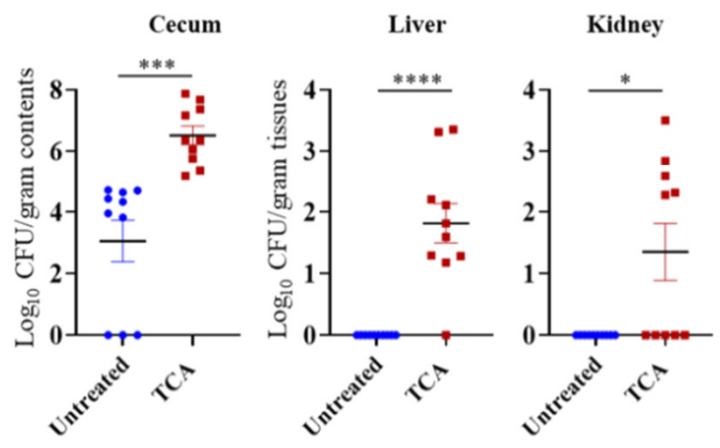

Figure 2. TCA alone induces fungal colonization and dissemination in the absence of antibiotics and immunosuppression. (A) Experimental outline. C57BL/6 mice infected with $\sim 2 \times 10^{8}$ CFU CA SC5314 via oral gavage. Untreated mice received sterile drinking water (untreated group); the treatment group received sterile water containing $1 \%$ TCA (TCA group). (B) Mice were monitored for survival. A log-rank test was performed using 95\% confidence intervals; statistical significance was calculated to compare the antibiotic-treated and untreated control groups. (C) Fungal load from feces collected from untreated and TCA groups 1-, 4-, 7-, and 12-days post-infection. (D) Fungal load from cecum, liver, and kidney from dead mice was collected immediately in the TCA-treated groups and mice euthanized 15 days post-infection for untreated groups. Ten mice per group were used, and the data represent mean $\pm \mathrm{SEM}$. Statistical significance was evaluated using the Mann-Whitney U test. $p$ values $\leq 0.05\left(^{*}\right), \leq 0.001\left(^{* * *}\right), \leq 0.0001\left(^{* * * *}\right)$ were considered statistically significant.

Fungal load in the feces of the TCA group was significantly higher starting day 4 post-infection compared to the untreated control groups (Figure 2C). Furthermore, the TCA-treated group had significantly higher fungal loads in the cecal content, liver, and kidney, whereas no CA was detected in the liver and kidney from the untreated mice (Figure 2D). These results indicate that TCA alone can induce fungal colonization and dissemination from the GI tract in the absence of antibiotics and (or) immunosuppression.

3.3. TCA Induces Fungal Colonization and Dissemination from the GI Tract of Immunosuppressed Mice in the Absence of Antibiotic Treatment

Since antibiotic-induced gut dysbiosis is necessary to induce CA colonization and dissemination in immunosuppressed mice (Figure 1A) [6], we tested whether administration of $1 \%$ TCA in the drinking water of immunosuppressed mice can promote fungal colonization and dissemination (Figure 3A). Interestingly, BALB/c mice that received TCA started to die 6 days post-cyclophosphamide injection, and all the mice were dead by day 9 after the first dose of cyclophosphamide. On the other hand, the mice that were infected with CA and received three doses of cyclophosphamide survived (Figure 3B). The fungal load was significantly increased in the cecal contents and liver of the TCA-treated group compared to the immunosuppressed mice that received only sterile drinking water (Figure $3 \mathrm{C}$ ). These results suggest that an increased concentration of TCA in the intestine promotes fungal colonization, dissemination, and mortality, even in the absence of antibiotic treatment in immunosuppressed mice. 
(A)

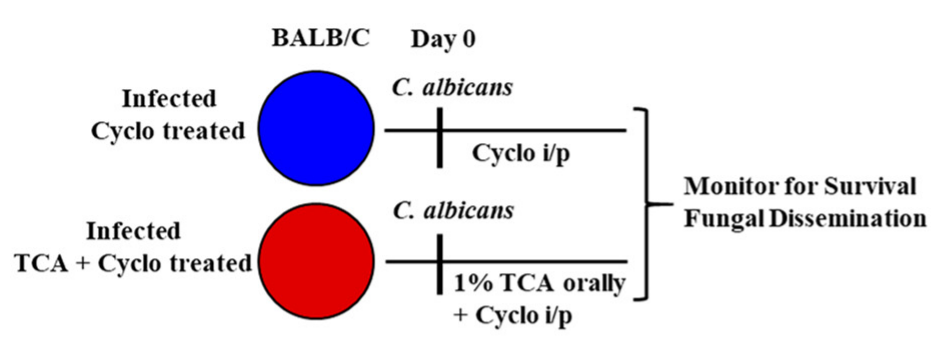

(B)

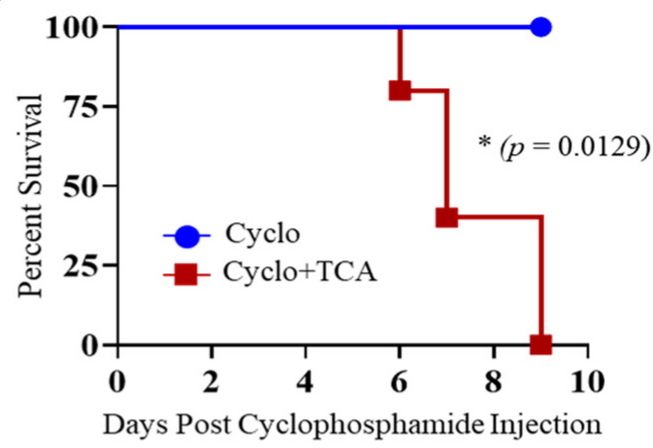

(C)

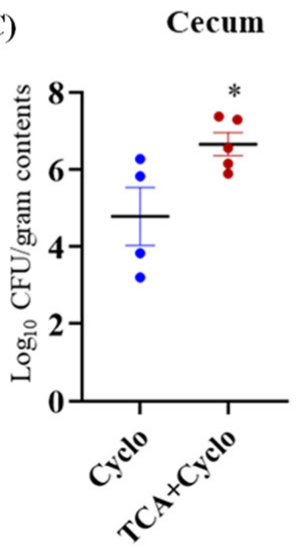

Liver

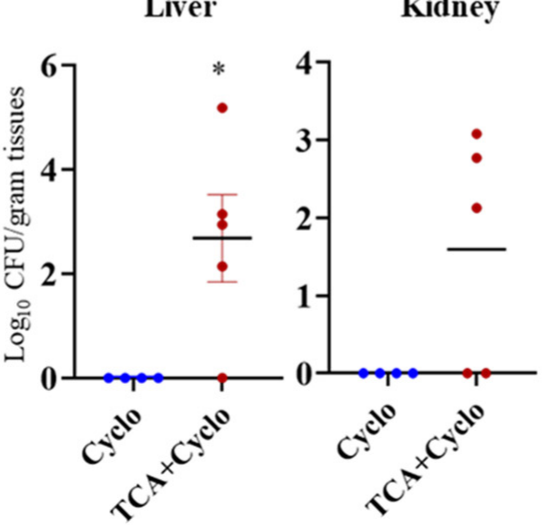

Figure 3. TCA induces fungal dissemination from the GI tract of immunosuppressed mice in the absence of antibiotic treatment. (A) Experimental outline. BALB/c mice infected with $\sim 2 \times 10^{8}$ CFU CA SC5314 via oral gavage received sterile water containing or not containing $1 \%$ TCA. Three days post-infection, all mice were injected with three doses of cyclophosphamide intraperitoneally (150 mg/ $\mathrm{kg}$ body weight). (B) Mice were monitored for survival, and a log-rank test was performed using 95\% confidence intervals; statistical significance was calculated to compare the antibiotic-treated and untreated control groups. (C) Fungal load from cecum, liver, and kidney collected immediately after death in the TCA+ cyclo-treated groups and mice euthanized 9 days post-infection for cyclo groups. 4-5 mice per group were used, and the data represent mean \pm SEM. Statistical significance was evaluated using the Mann-Whitney U test. $p$ values $\leq 0.05\left(^{*}\right)$ was considered statistically significant.

\subsection{TCA Enhanced Intestinal Permeability and Reduced the Expression of a Tight Junction Protein}

The intestinal barrier function is critical to prevent enteric pathogens from disseminating from the GI tract to systemic organs [6,53]. Since TCA treatment induced CA dissemination from the GI tract, we evaluated if TCA dysregulated the intestinal barrier function with a FITC-dextran permeability assay. The TCA-treated group had significantly increased levels of FITC-dextran in the blood compared to the untreated control groups (Figure 4A). Furthermore, the expression of the ZO-1 tight junction protein was decreased in the colon of TCA-treated mice (Figure 4B). Altogether, these results indicate that TCA dysregulates the intestinal barrier function, which may contribute to CA dissemination from the intestinal tract.

\subsection{TCA Down-Regulates ang4 and Cx3cr1 Expression in the Colon Tissue}

CA can cause severe invasive disease and mortality once critical components of the host defense system are compromised [6,53-56]. To identify if TCA dysregulates the intestinal host defense system to induce CA colonization and dissemination, colonic tissue from untreated and TCA-treated mice were collected after 10 days of CA infection, and were RNA-sequenced to examine the expression of host defense genes (Figure 5A). Among the host defense genes examined, the relative expression of angiogenin 4 (ang4), an 
antimicrobial peptide, and CX3CR1 (Cx3cr1), a chemokine receptor, was significantly downregulated in TCA-treated mice compared to untreated mice infected with CA (Figure 5A,B). Bile acids receptors play an important role in bile acid signaling [50,57-61]. Further, our findings indicate that among the receptors examined, the relative expression of Slc10a2 and Nr1h4 that encode the apical sodium-dependent bile acid transporter (ASBT) and farnesoid $X$ receptor (FXR) receptors, respectively, was increased in the TCA-treated mice compared to untreated groups infected with CA (Figure 5C).

(A)

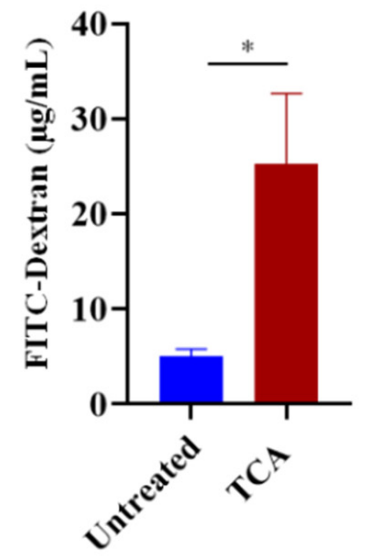

Untreated

(B)

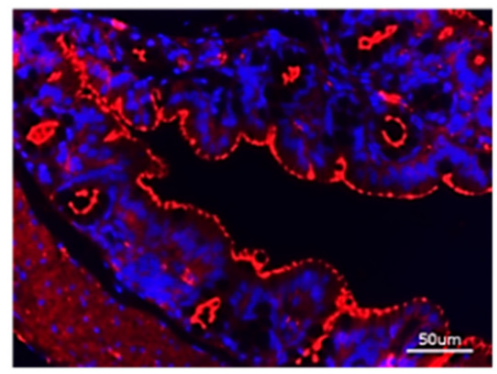

TCA

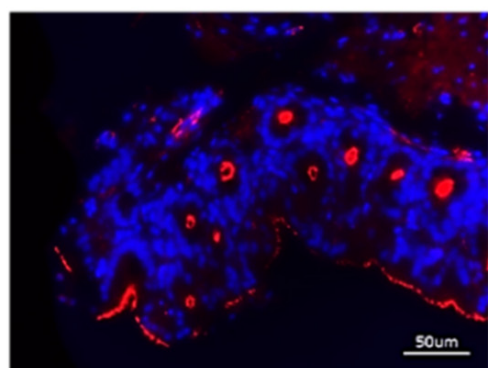

DAPI

ZO-1

Figure 4. TCA increases intestinal permeability leading to fungal dissemination from the GI tract. (A) Gut permeability was measured in infected mice using a FITC-dextran assay. At 10 days post-infection, male and female BL57/6J mice in both control and TCA-treated groups infected with CA were given an oral gavage of $150 \mu \mathrm{L}$ PBS containing 15 mg FITC-dextran. Four hours after administering FITC-dextran, mice were anesthetized, and blood was collected via retro-orbital bleed. Blood samples were processed via a two-fold serial dilution in a 96-well plate, and fluorescence was measured via a plate reader (excitation: $485 \mathrm{~nm}$; emission: $520 \mathrm{~nm}$ ). Data represent mean \pm SEM. Statistical significance was evaluated using the Mann-Whitney U test. $p$ values $\leq 0.05\left(^{*}\right)$ was considered statistically significant. (B) ZO-1 tight junction protein expression in untreated and TCA-treated mice. Colon tissue from untreated and TCA-treated mice from CA-infected mice (10 days post-infection) was stained with ZO-1 and DAPI antibodies. Representative images are shown here.

\subsection{TCA Alters Microbial Composition in Both Luminal and Mucosal Parts of the GI Tract}

Next, we examined if TCA changes the composition of intestinal microbiota, as commensal bacteria are also essential in providing colonization resistance to CA $[6,26]$. We analyzed the intestinal microbiota composition from the cecal contents and mucosal scrapings from the colon in the untreated control and TCA-treated mice infected with CA. Our results revealed that several culturable and unculturable bacterial members were significantly altered in cecal contents and colon mucosal scrapings in both groups (Supplementary Figures S1-S4, Figure 6A,B). Out of the top 20 statistically significant culturable and unculturable bacterial members found in cecal contents and colon mucosal scrapings (Figure 6A,B), we focused on culturable bacterial members whose $16 \mathrm{~s}$ reads could be mapped at species-level resolution. The relative abundance of three culturable bacterial members: Turicibacter sanguinis (cecum: $5.2 \%$ versus $0.90 \%$; colonic mucosa: $5.2 \%$ versus $0.65 \%$ ); Lactobacillus johnsonii (cecum: $26.4 \%$ versus $8.0 \%$; colonic mucosa: $24.6 \%$ versus $6.8 \%$ ); and Clostridium celatum (cecum: $5.3 \%$ versus $0.76 \%$; colonic mucosa: $4.3 \%$ versus $0.44 \%$ ) were significantly decreased in both cecal content and colon scrapings from TCA-treated mice compared to untreated mice (Figure 6C,D). In mucosal scrapings, L. johnsonii constituted close to $25 \%$ of $16 \mathrm{~s}$ reads, but was three times more depleted in mice fed with TCA-infused drinking water. Comparatively, the diminishment as a result of TCA was 6- to 7-fold for reads mapping to T. sanguinis and C. celatum. Taken together, the relative abundance of three culturable bacterial members (T. sanguinis, L. johnsonii, and C. celatum) were significantly decreased in both cecal content and colon scrapings from TCA-treated mice compared to untreated mice infected with CA. 
(A)

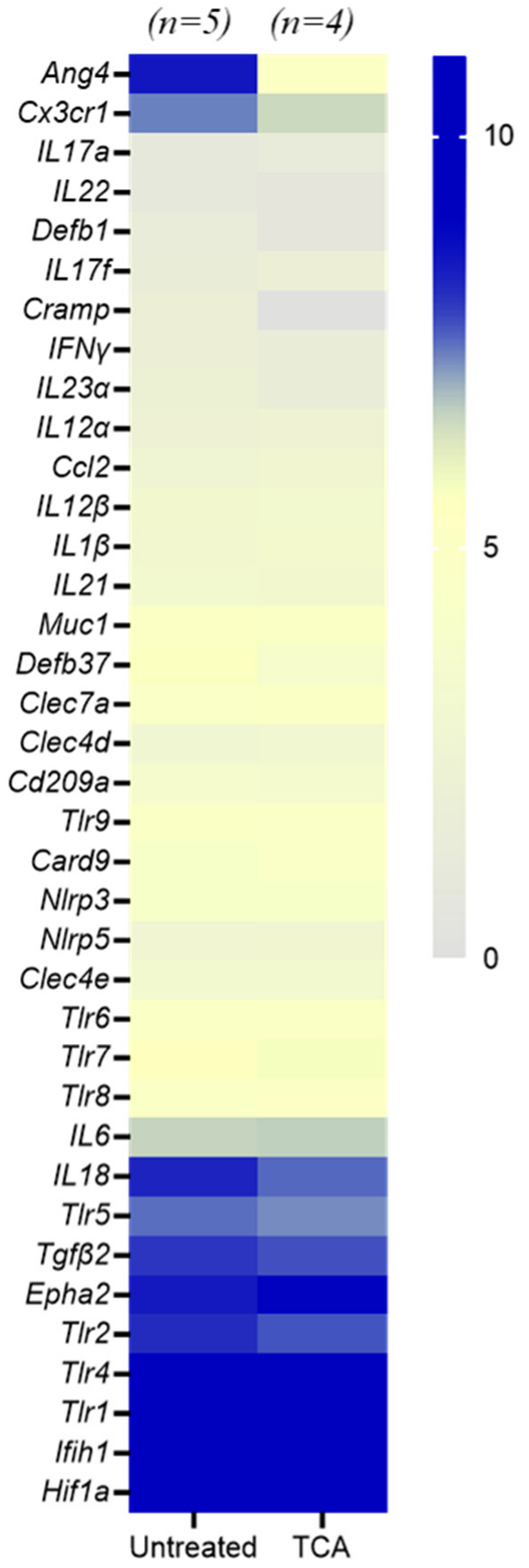

(B)

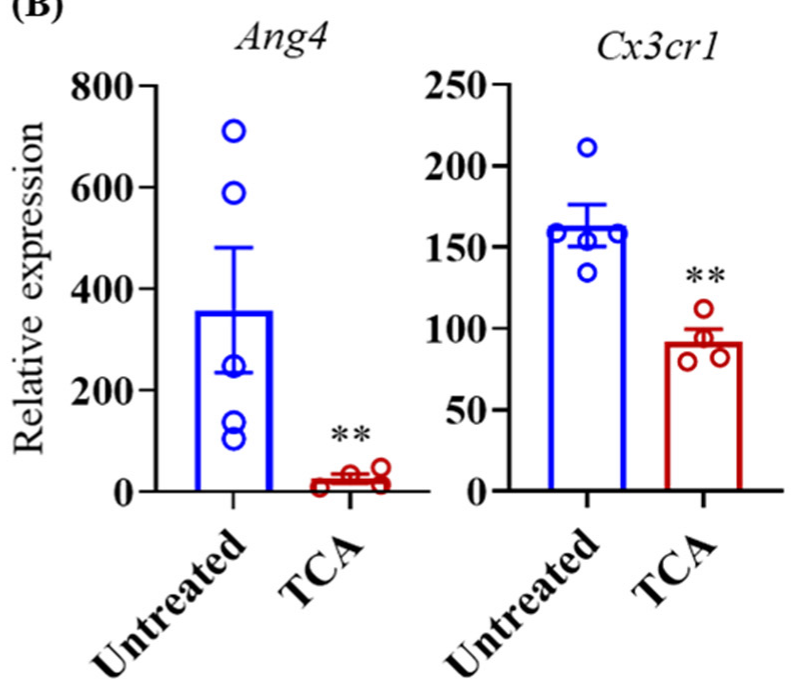

$$
(n=5) \quad(n=4)
$$

(C) Slc10a2Nr1h4Gpbar1Nr1i3Ffar3S1pr2Chrm3Nr4a1Ffar1Ffar2Nr1i2-

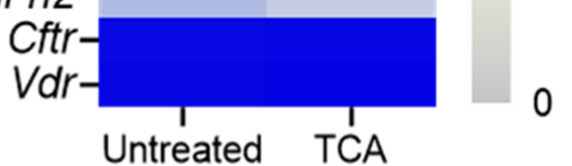

Figure 5. TCA inhibits the expression of ang 4 and CX3CR1 in the colon in vivo. Colon tissue from untreated and TCAtreated mice collected after 10 days of CA infection and treatment were RNA-sequenced to examine the expression level of host defense genes. (A) Average relative expression of host defense genes in untreated and TCA-treated mice is shown. (B) Relative expression of ang 4 and C $x 3 c r 1$ in untreated and TCA-treated mice is shown. (C) Average relative expression of intestinal metabolite receptors in untreated and TCA-treated mice is shown. Four to five mice per group were used. Data represent mean \pm SEM. Statistical significance was evaluated using the Student's $t$-test. $p$ values $\leq 0.01\left({ }^{* *}\right)$ was considered statistically significant. 


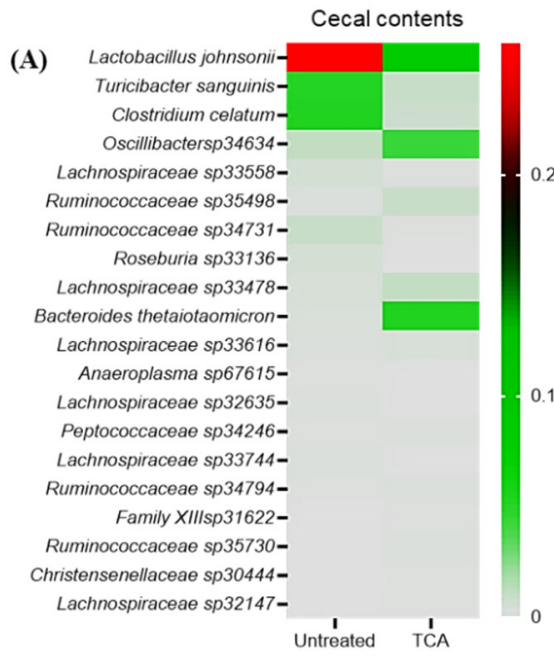

(C)

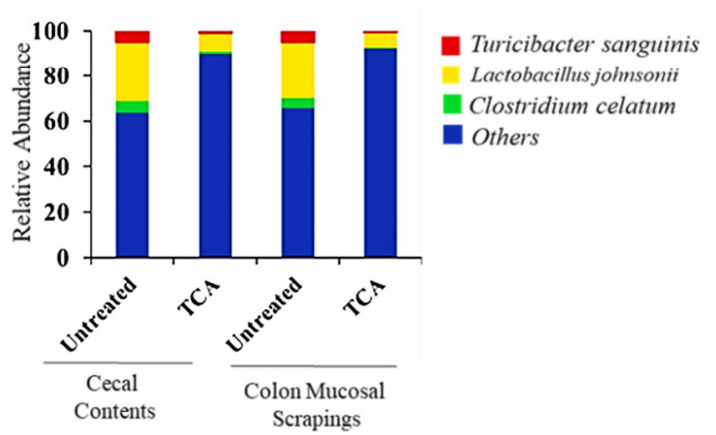

(B)

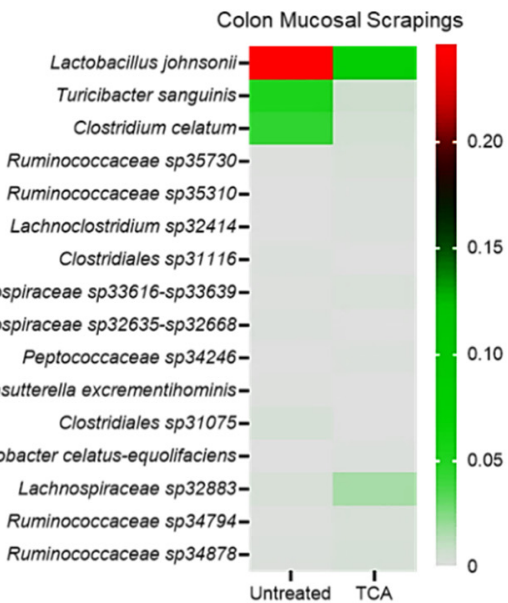

(D)

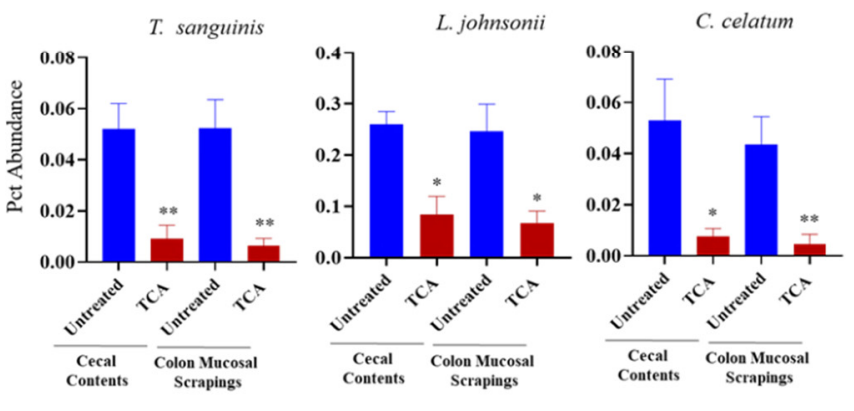

Figure 6. TCA alters the relative abundance of intestinal microbiota. C57BL/ 6 mice were infected with $\sim 2 \times 10^{8}$ CFU CA SC5314 via oral gavage. Control mice received sterile drinking water (untreated group); the treatment group received sterile water containing 1\% TCA (TCA group). Ten days post-infection, cecal contents and colon scrapings were collected to determine the relative abundance of intestinal microbiota. (A,B) Bacterial members that are significantly altered in the TCA group compared to the untreated control groups in cecal content and colon mucosal scrapings, respectively, are shown here. (C,D) Bacterial members that are significantly altered in the TCA group compared to the untreated control groups in both cecal content and colon mucosal scrapings are shown here. Five mice per group were used. Data represent mean \pm SEM. Statistical significance was evaluated using the Student's $t$-test. $p$ values $\leq 0.05\left(^{*}\right)$ or $\leq 0.01\left({ }^{* *}\right)$ were considered statistically significant.

\section{Discussion}

Our findings indicate that TCA is one of the most strongly up-regulated major bile acids in the antibiotic-treated mice susceptible to CA infection. After synthesis in the liver, TCA enters the small intestine and undergoes deconjugation and dihydroxylation, which are carried out by bile salt hydrolases and bile acid-inducible enzymes present in the gut microbes. These two chemical modifications convert TCA to DCA in the cecum $[48,57,62-67]$. Treatment with antibiotics decreases the microbial metabolism of TCA, and induces an increase of this bile acid. Treatment of wild-type and immunosuppressed mice with TCA alone promoted fungal colonization and dissemination from the GI tract in the absence of antibiotic treatment. Our studies revealed three primary mechanisms that underlie the TCA-induced enhanced CA colonization and dissemination from the GI tract, including: (i) deficiencies in host defense mechanisms; (ii) disruption of the commensal microbiota, which permits intestinal overgrowth of CA; and (iii) intestinal barrier dysfunction [6,53].

TCA significantly decreased the expression of $a n g 4$ and $C x 3 c r 1$ in the colon. Interestingly, both angiogenin-4 and CX3CR1 are involved in antifungal defense $[55,68]$. Mice have three orthologous ang antimicrobial peptide genes (ang 1, 3, and 4). However, only ang4 is highly expressed in the colon and small intestine, and is produced by goblet and Paneth cells [68-70]. Humans only have one orthologous protein (ANG). Both ang4 and ANG ex- 
hibit antifungal activity in vitro [68]. Similarly, CX3CR1, mainly expressed by macrophages in the intestine, plays a critical role in the antifungal defense to CA [55,71]. Furthermore, recent evidence indicates that CX3CR1-expressing macrophages are important to maintain intestinal barrier function to prevent bacterial translocation from the gut [72]. Mice dosed with $1 \%$ TCA orally had a significantly decreased abundance of L. johnsonii, T. sanguinis, and C. celatum in the cecal contents and colon mucosal scrapings. Interestingly, previous findings from our lab indicate that all these three bacterial genera were also decreased in antibiotic-treated mice susceptible to CA [26]. Commensal bacteria, such as L. johnsonii, play a critical role in maintaining the intestinal barrier function [73-76], and can directly inhibit the growth of fungi [77]. Since ang4 and $\mathrm{Cx} 3 \mathrm{cr} 1$ expression is also regulated by the microbiota [68,78], it is possible that TCA indirectly regulates CA by controlling ang4 and $\mathrm{C} \times 3 \mathrm{cr} 1$ expression through one of the three commensal bacteria modulated by TCA.

In the intestine, TCA is mainly absorbed through apical sodium-dependent bile acid transporter (ASBT), encoded by the Slc10a2 gene in ileal and colonic epithelial cells $[50,57,58]$. After absorption, TCA binds to FXR, a nuclear receptor encoded by Nr1h4, expressed in enterocytes and macrophages, resulting in the transcription of target genes [50,57,59-61]. The expression of Slc10a2 and Nr1h4 was also significantly increased in the colon of antibiotic-treated mice [50,79]. Therefore, these findings, along with others $[55,68,71,72]$, suggest that TCA may induce CA colonization and dissemination by controlling the intestinal defense system and barrier function through ASBT and FXR. Under normal physiological conditions, the intestine and cecum hold a bile salt concentration gradient ranging from $2 \%$ and $0.05 \%$ [80,81]. In addition, previous studies used $1 \%$ bile acids for mouse studies [82-86]. Therefore, we used an average concentration of $1 \%$ TCA in our experiments. However, the effect of TCA may differ depending on the intestinal concentration in the lumen. For example, a lower concentration $(0.1$ or $0.5 \%)$ may affect only microbiota or host, and can potentially enhance only CA colonization without dissemination. Further, in order to test the possibility that the metabolic transformation of orally administered TCA to DCA may contribute to host and microbiota alterations observed in our study, we also examined the DCA levels in TCA-treated mice. Surprisingly, mice that received TCA had considerably reduced levels of DCA compared to untreated groups (Supplementary Figure S5). This may be partly because TCA may directly inhibit certain species of bile-metabolizing bacteria, such as Lactobacillus species.

Not only does antibiotic treatment pre-dispose the host to invasive CA infections, a recent study by Zhai et al. [4] indicates that individuals undergoing allogeneic hematopoietic cell transplantation (allo-HCT) were highly susceptible to CA and Candida parapsilosis invasive infections. Furthermore, the authors demonstrated that invasive fungal infections in allo-HCT patients originated from the intestinal tract [4]. The majority of primary bile acids in humans are conjugated to taurine (or) glycine, unlike mice, where the major conjugation is to taurine. Furthermore, antibiotic treatment in humans $[87,88]$ and individuals undergoing allo-HCT [89], who are highly susceptible to invasive fungal infections, have increased levels of TCA and other primary bile acids, including glycocholic acid (GCA) and chenodeoxycholic acid (CDCA), which are also FXR ligands. Therefore, future studies to understand the role of primary bile acids on fungal colonization and its contribution to invasive fungal infections originating from the intestine is critical to gain insights into bile acid-mediated regulation of fungal infections in humans. The findings from our study spark several questions including: how does TCA impact the host defense system? What is the concentration-dependent effect of TCA on fungal colonization and dissemination? Do TCA and other primary bile acids, such as GCA and CDCA, affect other Candida pathogens, including C. parapsilosis, Candida tropicalis, and Candida auris? Can TCA alone promote fungal colonization and dissemination in the absence of microbiota? Can TCA alone cause intestinal barrier dysfunction in the absence of CA? In addition to the host and microbiota effect, TCA and (or) DCA may also have a direct effect on CA [26,90,91]. Given the significant alteration in bile acid levels during various therapies and diseases [30-52,92-113], understanding the direct and indirect mechanisms by which bile acids regulate fungal 
pathogens will provide a new approach to manipulate and control the fungal-bile communication system in favor of the host. In addition, CA in the gut also plays an active role in inflammatory bowel disease $[102,114,115]$, the microbiota-gut-brain axis $[116,117]$, and treating various pathogens, including Clostridium difficile [118,119]. Therefore, an in-depth understanding of the role of bile acid metabolites in affecting fungal colonization will form a strong platform to pursue therapies. Potential therapeutic strategies to prevent and treat invasive fungal infections and CA-associated intestinal diseases in humans could include the modulation of either the bile acids directly or bile-acid metabolizing commensal bacteria, or regulation of the host defense system through bile acid receptors.

Supplementary Materials: The following are available online at https://www.mdpi.com/article/10 .3390/jof7121030/s1, Table S1: Abundance of bile acids from cecal contents from individual mice samples; Figure S1: Bar graph showing the alpha diversity from cecal contents and mucosal scrapings from colon in the untreated and TCA treated mice groups infected with CA; Figures S2-S4: Heatmap showing the relative abundance of bacterial members (phylum, order and family) from cecal contents and mucosal scrapings from colon in the untreated and TCA treated mice groups infected with CA; Figure S5: TCA and DCA levels in the cecal contents from untreated and TCA treated mice infected with CA collected after 10-12 days of infection and treatment were shown here. 4-5 mice per group was used and the data represents mean \pm SEM. Statistical significance was evaluated using the student's $t$ test. $p$ values $\leq 0.05\left(^{*}\right)$ or $\leq 0.01\left(^{* *}\right)$ were considered statistically significant.

Author Contributions: Conceptualization, S.T.; methodology, S.T., R.M., J.K.L., H.G. and Y.J.; software and analysis, S.T., R.M., V.A., H.H., T.R.H.; resources, S.T.; data curation, S.T. and R.M.; writing—original draft preparation, S.T.; writing—review and editing, S.T., R.M., V.A., H.H., T.R.H. and G.L.G.; supervision, S.T.; project administration, S.T.; funding acquisition, S.T. All authors have read and agreed to the published version of the manuscript.

Funding: This study was supported by start-up fund from Midwestern University and Purdue University to Shankar Thangamani.

Institutional Review Board Statement: Male and female C57BL/6J mice (000664) and BALB/cJ mice (000651) of ages 6-12 weeks were purchased from the Jackson Laboratory. All animal studies conducted were approved by the Institutional Animal Care and Use Committee (IACUC) at Midwestern University under MWU IACUC Protocol \#4014.

Informed Consent Statement: Not applicable.

Data Availability Statement: Not applicable.

Conflicts of Interest: The authors declare no conflict of interest.

\section{References}

1. Angarone, M. Fungal infections in cancer patients. Cancer Treat. Res. 2014, 161, 129-155.

2. Low, C.-Y.; Rotstein, C. Emerging fungal infections in immunocompromised patients. F1000 Med. Rep. 2011, 3, 14. [CrossRef] [PubMed]

3. Perfect, J.R.; Hachem, R.; Wingard, J.R. Update on epidemiology of and preventive strategies for invasive fungal infections in cancer patients. Clin. Infect. Dis. Off. Publ. Infect. Dis. Soc. Am. 2014, 59 (Suppl. S5), S352-S355. [CrossRef] [PubMed]

4. Zhai, B.; Ola, M.; Rolling, T.; Tosini, N.L.; Joshowitz, S.; Littmann, E.R.; Amoretti, L.A.; Fontana, E.; Wright, R.J.; Miranda, E.; et al. High-resolution mycobiota analysis reveals dynamic intestinal translocation preceding invasive candidiasis. Nat. Med. 2020, 26, 59-64. [CrossRef]

5. Neville, B.A.; d'Enfert, C.; Bougnoux, M.E. Candida albicans commensalism in the gastrointestinal tract. FEMS Yeast Res. 2015, 15, fov081. [CrossRef]

6. Fan, D.; Coughlin, L.A.; Neubauer, M.M.; Kim, J.; Kim, M.S.; Zhan, X.; Simms-Waldrip, T.R.; Xie, Y.; Hooper, L.V.; Koh, A.Y. Activation of HIF-1 $\alpha$ and LL-37 by commensal bacteria inhibits Candida albicans colonization. Nat. Med. 2015, 21, 808-814. [CrossRef] [PubMed]

7. Huppert, M.; Cazin, J., Jr. Pathogenesis of Candida albicans infection following antibiotic therapy. II. Further studies of the effect of antibiotics on the in vitro growth of Candida albicans. J. Bacteriol. 1955, 70, 435-439. [CrossRef]

8. Krause, R.; Krejs, G.J.; Wenisch, C.; Reisinger, E.C. Elevated Fecal Candida Counts in Patients with Antibiotic-Associated Diarrhea: Role of Soluble Fecal Substances. Clin. Vaccine Immunol. 2003, 10, 167-168. [CrossRef]

9. Krause, R.; Schwab, E.; Bachhiesl, D.; Daxböck, F.; Wenisch, C.; Krejs, G.J.; Reisinger, E.C. Role of Candida in Antibiotic-Associated Diarrhea. J. Infect. Dis. 2001, 184, 1065-1069. [CrossRef] 
10. Schulte, D.M.; Sethi, A.K.; Gangnon, R.E.; Duster, M.; Maki, D.G.; Safdar, N. Risk factors for Candida colonization and Cocolonization with multi-drug resistant organisms at admission. Antimicrob. Resist. Infect. Control 2015, 4, 1-9. [CrossRef]

11. Guiot, H.F.; Fibbe, W.E.; van 't Wout, J.W. Risk factors for fungal infection in patients with malignant hematologic disorders: Implications for empirical therapy and prophylaxis. Clin. Infect. Dis. 1994, 18, 525-532. [CrossRef] [PubMed]

12. Guastalegname, M.; Russo, A.; Falcone, M.; Giuliano, S.; Venditti, M. Candidemia subsequent to severe infection due to Clos-tridium difficile: Is there a link? Clin. Infect. Dis. 2013, 57, 772-774. [CrossRef] [PubMed]

13. Nerandzic, M.M.; Mullane, K.; Miller, M.A.; Babakhani, F.; Donskey, C.J. Reduced acquisition and overgrowth of vancomycinresistant enterococci and Candida species in patients treated with fidaxomicin versus vancomycin for Clostridium difficile infection. Clin. Infect. Dis. 2012, 55 (Suppl. S2), S121-S126. [CrossRef]

14. Samonis, G.; Gikas, A.; Anaissie, E.J.; Vrenzos, G.; Maraki, S.; Tselentis, Y.; Bodey, G.P. Prospective evaluation of effects of broad-spectrum antibiotics on gastrointestinal yeast colonization of humans. Antimicrob. Agents Chemother. 1993, $37,51-53$. [CrossRef] [PubMed]

15. Wiesner, S.M.; Jechorek, R.P.; Garni, R.M.; Bendel, C.; Wells, C.L. Gastrointestinal Colonization by Candida albicans Mutant Strains in Antibiotic-Treated Mice. Clin. Diagn. Lab. Immunol. 2001, 8, 192-195. [CrossRef] [PubMed]

16. Ekenna, O.; Sherertz, R.J. Factors affecting colonization and dissemination of Candida albicans from the gastrointestinal tract of mice. Infect. Immun. 1987, 55, 1558-1563. [CrossRef]

17. Koh, A.Y. Murine Models of Candida Gastrointestinal Colonization and Dissemination. Eukaryot. Cell 2013, $12,1416-1422$. [CrossRef] [PubMed]

18. Prieto, D.; Pla, J. Distinct stages during colonization of the mouse gastrointestinal tract by Candida albicans. Front. Microbiol. 2015, 6, 792. [CrossRef]

19. Vautier, S.; Drummond, R.A.; Chen, K.; Murray, G.I.; Kadosh, D.; Brown, A.J.; Gow, N.A.; MacCallum, D.M.; Kolls, J.K.; Brown, G.D. Candida albicans colonization and dissemination from the murine gastrointestinal tract: The influence of morphology and Th17 immunity. Cell. Microbiol. 2015, 17, 445-450. [CrossRef]

20. Conti, H.R.; Huppler, A.R.; Whibley, N.; Gaffen, S.L. Animal Models for Candidiasis. Curr. Protoc. Immunol. 2014, 105, 19.6.1-19.6.17. [CrossRef]

21. Mason, K.L.; Erb Downward, J.R.; Mason, K.D.; Falkowski, N.R.; Eaton, K.A.; Kao, J.Y.; Young, V.B.; Huffnagle, G.B. Candida albicans and bacterial microbiota interactions in the cecum during recolonization following broad-spectrum antibiotic therapy. Infect. Immun. 2012, 80, 3371-3380. [CrossRef]

22. Erb Downward, J.R.; Falkowski, N.R.; Mason, K.L.; Muraglia, R.; Huffnagle, G.B. Modulation of post-antibiotic bacterial community reassembly and host response by Candida albicans. Sci. Rep. 2013, 3, 2191. [CrossRef] [PubMed]

23. Suez, J.; Elinav, E. The path towards microbiome-based metabolite treatment. Nat. Microbiol. 2017, 2, 17075. [CrossRef] [PubMed]

24. Buffie, C.G.; Bucci, V.; Stein, R.R.; McKenney, P.T.; Ling, L.; Gobourne, A.; No, D.; Liu, H.; Kinnebrew, M.; Viale, A.; et al. Precision microbiome reconstitution restores bile acid mediated resistance to Clostridium difficile. Nature 2015, 517, 205-208. [CrossRef]

25. Kohli, N.; Crisp, Z.; Riordan, R.; Li, M.; Alaniz, R.C.; Jayaraman, A. The microbiota metabolite indole inhibits Salmonella virulence: Involvement of the PhoPQ two-component system. PLoS ONE 2018, 13, e0190613. [CrossRef] [PubMed]

26. Gutierrez, D.; Weinstock, A.; Antharam, V.C.; Gu, H.; Jasbi, P.; Shi, X.; Dirks, B.; Krajmalnik-Brown, R.; Maldonado, J.; Guinan, J.; et al. Antibiotic-induced gut metabolome and microbiome alterations increase the susceptibility to Candida albicans colonization in the gastrointestinal tract. FEMS Microbiol. Ecol. 2020, 96, fiz187. [CrossRef]

27. Chiang, J.Y.L. Bile Acid Metabolism and Signaling. Compr. Physiol. 2013, 3, 1191-1212. [CrossRef]

28. Staels, B.; Fonseca, V.A. Bile Acids and Metabolic Regulation: Mechanisms and clinical responses to bile acid sequestration. Diabetes Care 2009, 32, S237-S245. [CrossRef]

29. Sayin, S.I.; Wahlstrom, A.; Felin, J.; Jantti, S.; Marschall, H.U.; Bamberg, K.; Angelin, B.; Hyotylainen, T.; Oresic, M.; Backhed, F. Gut microbiota regulates bile acid metabolism by reducing the levels of tauro-beta-muricholic acid, a naturally occurring FXR antagonist. Cell. Metab. 2013, 17, 225-235. [CrossRef]

30. Song, W.-S.; Park, H.-M.; Ha, J.M.; Shin, S.G.; Park, H.-G.; Kim, J.; Zhang, T.; Ahn, D.-H.; Kim, S.-M.; Yang, Y.-H.; et al. Discovery of glycocholic acid and taurochenodeoxycholic acid as phenotypic biomarkers in cholangiocarcinoma. Sci. Rep. 2018, 8, 1-8. [CrossRef]

31. Manieri, E.; Folgueira, C.; Rodríguez, M.E.; Leiva-Vega, L.; Esteban-Lafuente, L.; Chen, C.; Cubero, F.J.; Barrett, T.; CavanaghKyros, J.; Seruggia, D.; et al. JNK-mediated disruption of bile acid homeostasis promotes intrahepatic cholangiocarcinoma. Proc. Natl. Acad. Sci. USA 2020, 117, 16492-16499. [CrossRef]

32. Kühn, T.; Stepien, M.; López-Nogueroles, M.; Damms-Machado, A.; Sookthai, D.; Johnson, T.; Roca, M.; Hüsing, A.; Maldonado, S.G.; Cross, A.J.; et al. Prediagnostic Plasma Bile Acid Levels and Colon Cancer Risk: A Prospective Study. J. Natl. Cancer Inst. 2020, 112, 516-524. [CrossRef] [PubMed]

33. Tian, Q.; Yang, R.; Wang, Y.; Liu, J.; Wee, A.; Saxena, R.; Wang, L.; Li, M.; Liu, L.; Shan, S.; et al. A High Serum Level of Taurocholic Acid Is Correlated with the Severity and Resolution of Drug-induced Liver Injury. Clin. Gastroenterol. Hepatol. 2021, 19, 1009-1019.e11. [CrossRef] [PubMed]

34. Luo, L.; Aubrecht, J.; Li, D.; Warner, R.L.; Johnson, K.J.; Kenny, J.; Colangelo, J.L. Assessment of serum bile acid profiles as biomarkers of liver injury and liver disease in humans. PLoS ONE 2018, 13, e0193824. [CrossRef] 
35. Ridlon, J.M.; Wolf, P.G.; Gaskins, H.R. Taurocholic acid metabolism by gut microbes and colon cancer. Gut Microbes 2016, 7, 201-215. [CrossRef]

36. Devkota, S.; Wang, Y.; Musch, M.W.; Leone, V.; Fehlner-Peach, H.; Nadimpalli, A.; Antonopoulos, D.A.; Jabri, B.; Chang, E.B. Dietary-fat-induced taurocholic acid promotes pathobiont expansion and colitis in $1110^{-/-}$mice. Nature 2012, 487, $104-108$. [CrossRef]

37. Liu, Z.; Zhang, Z.; Huang, M.; Sun, X.; Liu, B.; Guo, Q.; Chang, Q.; Duan, Z. Taurocholic acid is an active promoting factor, not just a biomarker of progression of liver cirrhosis: Evidence from a human metabolomic study and in vitro experiments. $B M C$ Gastroenterol. 2018, 18, 112. [CrossRef] [PubMed]

38. Bajaj, J.S.; Liu, E.J.; Kheradman, R.; Fagan, A.; Heuman, D.M.; White, M.; Gavis, E.A.; Hylemon, P.; Sikaroodi, M.; Gillevet, P.M. Fungal dysbiosis in cirrhosis. Gut 2017, 67, 1146-1154. [CrossRef] [PubMed]

39. Maraolo, A.E.; Scotto, R.; Zappulo, E.; Pinchera, B.; Moriello, N.S.; Nappa, S.; Buonomo, A.R.; Gentile, I. Novel strategies for the management of bacterial and fungal infections in patients with liver cirrhosis: Focus on new antimicrobials. Expert Rev. Anti-Infect. Ther. 2020, 18, 191-202. [CrossRef]

40. Li, B.; Yang, C.; Qian, Z.; Huang, Y.; Wang, X.; Zhong, G.; Chen, J. Spontaneous Fungal Ascites Infection in Patients with Cirrhosis: An Analysis of 10 Cases. Infect. Dis. Ther. 2021, 10, 1033-1043. [CrossRef]

41. Fiore, M.; Leone, S. Spontaneous fungal peritonitis: Epidemiology, current evidence and future prospective. World J. Gastroenterol. 2016, 22, 7742-7747. [CrossRef] [PubMed]

42. Ferrarese, A.; Cattelan, A.; Cillo, U.; Gringeri, E.; Russo, F.P.; Germani, G.; Gambato, M.; Burra, P.; Senzolo, M. Invasive fungal infec-tion before and after liver transplantation. World J. Gastroenterol. 2020, 26, 7485-7496. [CrossRef]

43. Ethanic, M.; Stanimirov, B.; Pavlovic, N.; Golocorbin-Kon, S.; Al-Salami, H.; Stankov, K.; Mikov, M. Pharmacological Applications of Bile Acids and Their Derivatives in the Treatment of Metabolic Syndrome. Front. Pharmacol. 2018, 9, 1382.

44. Li, T.; Chiang, J.Y.L. Bile acid-based therapies for non-alcoholic steatohepatitis and alcoholic liver disease. Hepatobiliary Surg. Nutr. 2020, 9, 152-169. [CrossRef] [PubMed]

45. Chiang, J.Y.; Ferrell, J.M. Bile Acid Biology, Pathophysiology, and Therapeutics. Clin. Liver Dis. 2020, 15, 91-94. [CrossRef] [PubMed]

46. Zhang, Y.; Limaye, P.B.; Renaud, H.J.; Klaassen, C.D. Effect of various antibiotics on modulation of intestinal microbiota and bile acid profile in mice. Toxicol. Appl. Pharmacol. 2014, 277, 138-145. [CrossRef] [PubMed]

47. Culpepper, T.; Rowe, C.C.; Rusch, C.T.; Burns, A.M.; Federico, A.P.; Girard, S.A.; Tompkins, T.A.; Nieves, C.; Dennis-Wall, J.C., Jr.; Christman, M.C.; et al. Three probiotic strains exert different effects on plasma bile acid profiles in healthy obese adults: Randomised, double-blind placebo-controlled crossover study. Benef. Microbes 2019, 10, 497-509. [CrossRef]

48. Begley, M.; Hill, C.; Gahan, C.G.M. Bile Salt Hydrolase Activity in Probiotics. Appl. Environ. Microbiol. 2006, 72, 1729-1738. [CrossRef]

49. Vrieze, A.; Out, C.; Fuentes, S.; Jonker, L.; Reuling, I.; Kootte, R.S.; van Nood, E.; Holleman, F.; Knaapen, M.; Romijn, J.A.; et al Impact of oral vancomycin on gut microbiota, bile acid metabolism, and insulin sensitivity. J. Hepatol. 2014, 60, 824-831. [CrossRef]

50. Zarrinpar, A.; Chaix, A.; Xu, Z.Z.; Chang, M.W.; Marotz, C.A.; Saghatelian, A.; Knight, R.; Panda, S. Antibiotic-induced microbiome depletion alters metabolic homeostasis by affecting gut signaling and colonic metabolism. Nat. Commun. 2018, 9 , 2872. [CrossRef]

51. Mooranian, A.; Zamani, N.; Mikov, M.; Goločorbin-Kon, S.; Stojanovic, G.; Arfuso, F.; Al-Salami, H. Stability and biological testing of taurine-conjugated bile acid antioxidant microcapsules for diabetes treatment. Ther. Deliv. 2019, 10, 99-106. [CrossRef] [PubMed]

52. Khatun, Z.; Nurunnabi, M.; Reeck, G.R.; Cho, K.J.; Lee, Y.-K. Oral delivery of taurocholic acid linked heparin-docetaxel conjugates for cancer therapy. J. Control Release 2013, 170, 74-82. [CrossRef] [PubMed]

53. Koh, A.Y.; Kohler, J.R.; Coggshall, K.T.; Van Rooijen, N.; Pier, G.B. Mucosal damage and neutropenia are required for Candida albicans dissemination. PLoS Pathog. 2008, 4, e35. [CrossRef]

54. Netea, M.G.; Joosten, L.A.; van der Meer, J.W.; Kullberg, B.J.; van de Veerdonk, F.L. Immune defence against Candida fungal infec-tions. Nat. Rev. Immunol. 2015, 15, 630-642. [CrossRef] [PubMed]

55. Leonardi, I.; Li, X.; Semon, A.; Li, D.; Doron, I.; Putzel, G.; Bar, A.; Prieto, D.; Rescigno, M.; McGovern, D.P.B.; et al. CX3CR1(+) mononuclear phagocytes control immunity to intestinal fungi. Science 2018, 359, 232-236. [CrossRef]

56. Drummond, R.; Gaffen, S.L.; Hise, A.G.; Brown, G. Innate Defense against Fungal Pathogens. Cold Spring Harb. Perspect. Med. 2015, 5, a019620. [CrossRef]

57. Wahlström, A.; Sayin, S.I.; Marschall, H.-U.; Bäckhed, F. Intestinal Crosstalk between Bile Acids and Microbiota and Its Impact on Host Metabolism. Cell Metab. 2016, 24, 41-50. [CrossRef]

58. Dekaney, C.M.; von Allmen, D.C.; Garrison, A.P.; Rigby, R.; Lund, P.K.; Henning, S.J.; Helmrath, M.A. Bacterial-dependent up-regulation of intestinal bile acid binding protein and transport is FXR-mediated following ileocecal resection. Surgery 2008, 144, 174-181. [CrossRef]

59. Fiorucci, S.; Biagioli, M.; Zampella, A.; Distrutti, E. Bile Acids Activated Receptors Regulate Innate Immunity. Front. Immunol. 2018, 9, 1853. [CrossRef]

60. Vavassori, P.; Mencarelli, A.; Renga, B.; Distrutti, E.; Fiorucci, S. The Bile Acid Receptor FXR Is a Modulator of Intestinal Innate Immunity. J. Immunol. 2009, 183, 6251-6261. [CrossRef] 
61. Li, L.; Zhang, Q.; Peng, J.; Jiang, C.; Zhang, Y.; Shen, L.; Dong, J.; Wang, Y.; Jiang, Y. Activation of farnesoid X receptor downregulates monocyte chemoattractant protein-1 in murine macrophage. Biochem. Biophys. Res. Commun. 2015, 467, 841-846. [CrossRef]

62. Ridlon, J.M.; Kang, D.J.; Hylemon, P.B.; Bajaj, J.S. Bile acids and the gut microbiome. Curr. Opin. Gastroenterol. 2014, 30, 332-338. Available online: https:// pubmed.ncbi.nlm.nih.gov/24625896 (accessed on 18 November 2021). [CrossRef]

63. Ramirez-Perez, O.; Cruz-Ramon, V.; Chinchilla-Lopez, P.; Mendez-Sanchez, N. The Role of the Gut Microbiota in Bile Acid Metabolism. Ann. Hepatol. 2017, 16 (Suppl. S1), S15-S20. [CrossRef] [PubMed]

64. Ridlon, J.M.; Harris, S.C.; Bhowmik, S.; Kang, D.J.; Hylemon, P.B. Consequences of bile salt biotransformations by intestinal bacteria. Gut Microbes 2016, 7, 22-39. [CrossRef] [PubMed]

65. Ridlon, J.M.; Hylemon, P.B. Identification and characterization of two bile acid coenzyme A transferases from Clostridium scindens, a bile acid 7 $\alpha$-dehydroxylating intestinal bacterium. J. Lipid Res. 2012, 53, 66-76. [CrossRef] [PubMed]

66. Ridlon, J.M.; Kang, D.J.; Hylemon, P.B. Bile salt biotransformations by human intestinal bacteria. J. Lipid Res. 2006, 47, 241-259. Available online: https://pubmed.ncbi.nlm.nih.gov/16299351/ (accessed on 26 December 2020). [CrossRef]

67. O'Flaherty, S.; Crawley, A.B.; Theriot, C.M.; Barrangou, R. The Lactobacillus Bile Salt Hydrolase Repertoire Reveals Niche-Specific Adaptation. mSphere 2018, 3, e00140-18. [CrossRef] [PubMed]

68. Hooper, L.V.; Stappenbeck, T.S.; Hong, C.V.; Gordon, J.I. Angiogenins: A new class of microbicidal proteins involved in innate immunity. Nat. Immunol. 2003, 4, 269-273. [CrossRef] [PubMed]

69. Forman, R.A.; Deschoolmeester, M.L.; Hurst, R.J.M.; Wright, S.H.; Pemberton, A.D.; Else, K.J. The Goblet Cell Is the Cellular Source of the Anti-Microbial Angiogenin 4 in the Large Intestine Post Trichuris muris Infection. PLoS ONE 2012, 7, e42248. [CrossRef]

70. Walker, C.R.; Hautefort, I.; Dalton, J.; Overweg, K.; Egan, C.E.; Bongaerts, R.J.; Newton, D.J.; Cruickshank, S.; Andrew, E.M.; Carding, S.R. Intestinal Intraepithelial Lymphocyte-Enterocyte Crosstalk Regulates Production of Bactericidal Angiogenin 4 by Paneth Cells upon Microbial Challenge. PLOS ONE 2013, 8, e84553. [CrossRef]

71. Doron, I.; Leonardi, I.; Li, X.V.; Fiers, W.D.; Semon, A.; Bialt-DeCelie, M.; Migaud, M.; Gao, I.H.; Lin, W.Y.; Kusakabe, T.; et al. Human gut mycobiota tune immunity via CARD9-dependent induction of anti-fungal IgG antibodies. Cell 2021, 184, 10171031.e14. [CrossRef] [PubMed]

72. Medina-Contreras, O.; Geem, D.; Laur, O.; Williams, I.R.; Lira, S.A.; Nusrat, A.; Parkos, C.A.; Denning, T. CX3CR1 regulates intestinal macrophage homeostasis, bacterial translocation, and colitogenic Th17 responses in mice. J. Clin. Investig. 2011, 121, 4787-4795. [CrossRef] [PubMed]

73. Liu, H.Y.; Roos, S.; Jonsson, H.; Ahl, D.; Dicksved, J.; Lindberg, J.E.; Lundh, T. Effects of Lactobacillus johnsonii and Lactobacillus reuteri on gut barrier function and heat shock proteins in intestinal porcine epithelial cells. Physiol. Rep. 2015, 3, e12355. [CrossRef] [PubMed]

74. Antonini, M.; Lo Conte, M.; Sorini, C.; Falcone, M. How the Interplay Between the Commensal Microbiota, Gut Barrier Integrity, and Mucosal Immunity Regulates Brain Autoimmunity. Front. Immunol. 2019, 10, 1937. [CrossRef]

75. Guo, W.; Zhou, X.; Li, X.; Zhu, Q.; Peng, J.; Zhu, B.; Zheng, X.; Lu, Y.; Yang, D.; Wang, B.; et al. Depletion of Gut Microbiota Impairs Gut Barrier Function and Antiviral Immune Defense in the Liver. Front. Immunol. 2021, 12, 897. [CrossRef]

76. Hiippala, K.; Jouhten, H.; Ronkainen, A.; Hartikainen, A.; Kainulainen, V.; Jalanka, J.; Satokari, R. The Potential of Gut Commensals in Reinforcing Intestinal Barrier Function and Alleviating Inflammation. Nutrients 2018, 10, 988. [CrossRef]

77. Charlet, R.; Bortolus, C.; Sendid, B.; Jawhara, S. Bacteroides thetaiotaomicron and Lactobacillus johnsonii modulate intestinal inflammation and eliminate fungi via enzymatic hydrolysis of the fungal cell wall. Sci. Rep. 2020, 10, 11510. [CrossRef]

78. Honda, M.; Surewaard, B.G.J.; Watanabe, M.; Hedrick, C.C.; Lee, W.-Y.; Brown, K.; McCoy, K.D.; Kubes, P. Perivascular localization of macrophages in the intestinal mucosa is regulated by Nr4a1 and the microbiome. Nat. Commun. 2020, 11, 1329. [CrossRef]

79. Out, C.; Patankar, J.V.; Doktorova, M.; Boesjes, M.; Bos, T.; de Boer, S.; Havinga, R.; Wolters, H.; Boverhof, R.; van Dijk, T.H.; et al. Gut microbiota inhibit Asbt-dependent intestinal bile acid reabsorption via Gata4. J. Hepatol. 2015, 63, 697-704. [CrossRef]

80. Islam, K.B.; Fukiya, S.; Hagio, M.; Fujii, N.; Ishizuka, S.; Ooka, T.; Ogura, Y.; Hayashi, T.; Yokota, A. Bile acid is a host factor that regu-lates the composition of the cecal microbiota in rats. Gastroenterology 2011, 141, 1773-1781. [CrossRef]

81. Ruiz, L.; Margolles, A.; Sánchez, B. Bile resistance mechanisms in Lactobacillus and Bifidobacterium. Front. Microbiol. 2013, 4, 396. [CrossRef] [PubMed]

82. Masson, D.; Lagrost, L.; Athias, A.; Gambert, P.; Brimer-Cline, C.; Lan, L.; Schuetz, J.D.; Schuetz, E.G.; Assem, M. Expression of the Pregnane X Receptor in Mice Antagonizes the Cholic Acid-Mediated Changes in Plasma Lipoprotein Profile. Arter. Thromb. Vasc. Biol. 2005, 25, 2164-2169. [CrossRef] [PubMed]

83. Fu, K.L.; Chen, P.; Zhou, Y.Y.; Jiang, Y.M.; Gao, Y.; Zhang, H.Z.; Guan, L.H.; Wang, C.H.; Liu, J.L.; Huang, M.; et al. Hepatic Vps33b deficiency aggravates cholic acid-induced cholestatic liver injury in male mice. Acta Pharmacol. Sin. 2021. [CrossRef]

84. Nguyen, J.T.; Riessen, R.R.; Zhang, T.; Kieffer, C.; Anakk, S. Deletion of Intestinal SHP Impairs Short-term Response to Cholic Acid Challenge in Male Mice. Endocrinology 2021, 162, bqab063. [CrossRef] [PubMed]

85. Srivastava, R.A.; Srivastava, N.; Averna, M. Dietary cholic acid lowers plasma levels of mouse and human apolipoprotein A-I primarily via a transcriptional mechanism. Eur. J. Biochem. 2000, 267, 4272-4280. [CrossRef] [PubMed] 
86. Fickert, P.; Zollner, G.; Fuchsbichler, A.; Stumptner, C.; Pojer, C.; Zenz, R.; Lammert, F.; Stieger, B.; Meier, P.J.; Zatloukal, K.; et al. Effects of Ursodeoxycholic and Cholic Acid Feeding on Hepatocellular Transporter Expression in Mouse Liver. Gastroenterology 2001, 121, 170-183. [CrossRef]

87. Robinson, J.I.; Weir, W.H.; Crowley, J.R.; Hink, T.; Reske, K.A.; Kwon, J.H.; Burnham, C.D.; Dubberke, E.R.; Mucha, P.J.; Henderson, J.P. Metabolomic networks connect host-microbiome processes to human Clostridioides difficile infections. J. Clin. Investig. 2019, 129, 3792-3806. [CrossRef]

88. Patton, L.; Li, N.; Garrett, T.; Ruoss, J.; Russell, J.; De La Cruz, D.; Bazacliu, C.; Polin, R.; Triplett, E.; Neu, J. Antibiotics Effects on the Fecal Metabolome in Preterm Infants. Metabolites 2020, 10, 331. [CrossRef]

89. Reikvam, H.; Grønningsæter, I.-S.; Mosevoll, K.A.; Lindås, R.; Hatfield, K.; Bruserud, Ø. Patients with Treatment-Requiring Chronic Graft versus Host Disease after Allogeneic Stem Cell Transplantation Have Altered Metabolic Profiles due to the Disease and Immunosuppressive Therapy: Potential Implication for Biomarkers. Front. Immunol. 2018, 8, 1979. [CrossRef]

90. Guinan, J.; Villa, P.; Thangamani, S. Secondary bile acids inhibit Candida albicans growth and morphogenesis. Pathog. Dis. 2018, 76, fty038. [CrossRef]

91. Guinan, J.; Thangamani, S. Antibiotic-induced alterations in taurocholic acid levels promote gastrointestinal colonization of Candida albicans. FEMS Microbiol. Lett. 2018, 365, fny196. [CrossRef]

92. Meadows, V.; Kennedy, L.; Kundu, D.; Alpini, G.; Francis, H. Bile Acid Receptor Therapeutics Effects on Chronic Liver Diseases. Front. Med. 2020, 7, 15. [CrossRef] [PubMed]

93. Dayan, S.H.; Humphrey, S.; Jones, D.H.; Lizzul, P.F.; Gross, T.M.; Stauffer, K.; Beddingfield, F.C., 3rd. Overview of ATX-101 (Deoxycholic Acid Injection): A Nonsurgical Approach for Reduction of Submental Fat. Dermatol. Surg. 2016, 42 (Suppl. S1), S263-S270. [CrossRef] [PubMed]

94. Beer, K.; Weinkle, S.H.; Cox, S.E.; Rubin, M.G.; Shamban, A.; Somogyif, C. ATX-101 (Deoxycholic Acid Injection) for Reduction of Submental Fat: Results From a 12-Month Open-Label Study. J. Drugs Dermatol. 2019, 18, 870-877. [PubMed]

95. Daruich, A.; Picard, E.; Boatright, J.H.; Behar-Cohen, F. Review: The bile acids urso- and tauroursodeoxycholic acid as neuroprotective therapies in retinal disease. Mol. Vis. 2019, 25, 610-624.

96. Gordon, S.C.; Wu, K.H.; Lindor, K.; Bowlus, C.L.; Rodriguez, C.V.; Anderson, H.; Boscarino, J.A.; Trudeau, S.; Rupp, L.B.; Haller, I.V.; et al. Ursodeoxycholic Acid Treatment Preferentially Improves Overall Survival Among African Americans With Primary Biliary Cholangitis. Am. J. Gastroenterol. 2020, 115, 262-270. [CrossRef]

97. Xiao, Y.; Zhou, K.; Lu, Y.; Yan, W.; Cai, W.; Wang, Y. Administration of antibiotics contributes to cholestasis in pediatric patients with intestinal failure via the alteration of FXR signaling. Exp. Mol. Med. 2018, 50, 1-14. [CrossRef]

98. Singla, P.; Dalal, P.; Kaur, M.; Arya, G.; Nimesh, S.; Singh, R.; Salunke, D.B. Bile Acid Oligomers and Their Combination with Antibiotics to Combat Bacterial Infections. J. Med. Chem. 2018, 61, 10265-10275. [CrossRef]

99. Winston, J.A.; Theriot, C.M. Diversification of host bile acids by members of the gut microbiota. Gut Microbes 2019, 11, 158-171. [CrossRef]

100. Sinha, S.R.; Haileselassie, Y.; Nguyen, L.P.; Tropini, C.; Wang, M.; Becker, L.S.; Sim, D.; Jarr, K.; Spear, E.T.; Singh, G.; et al. Dysbiosis-Induced Secondary Bile Acid Deficiency Promotes Intestinal Inflammation. Cell Host Microbe 2020, 27, 659-670.e655. [CrossRef] [PubMed]

101. Trojanowska, D.; Zwolinska-Wcislo, M.; Tokarczyk, M.; Kosowski, K.; Mach, T.; Budak, A. The role of Candida in inflammatory bowel disease. Estimation of transmission of $\mathrm{C}$. albicans fungi in gastrointestinal tract based on genetic affinity between strains. Med. Sci. Monit. 2010, 16, 451-457.

102. Gerard, R.; Sendid, B.; Colombel, J.F.; Poulain, D.; Jouault, T. An immunological link between Candida albicans colonization and Crohn's disease. Crit. Rev. Microbiol. 2015, 41, 135-139. [CrossRef]

103. Iliev, I.D.; Funari, V.A.; Taylor, K.D.; Nguyen, Q.; Reyes, C.N.; Strom, S.P.; Brown, J.; Becker, C.A.; Fleshner, P.R.; Dubinsky, M.; et al. Interactions between commensal fungi and the C-type lectin receptor Dectin-1 influence colitis. Science 2012, 336, 1314-1317. [CrossRef]

104. Leonardi, I.; Paramsothy, S.; Doron, I.; Semon, A.; Kaakoush, N.O.; Clemente, J.C.; Faith, J.J.; Borody, T.J.; Mitchell, H.M.; Colombel, J.F.; et al. Fungal Trans-kingdom Dynamics Linked to Responsiveness to Fecal Microbiota Transplantation (FMT) Therapy in Ul-cerative Colitis. Cell Host Microbe 2020, 27, 823-829.e823. [CrossRef] [PubMed]

105. Wajszczuk, C.P.; Dummer, J.S.; Ho, M.; Van Thiel, D.H.; Starzl, T.E.; Iwatsuki, S.; Shaw, B., Jr. Fungal infections in liver transplant recipients. Transplantation 1985, 40, 347-353. [CrossRef] [PubMed]

106. Brumble, L.; Keaveny, A.P. Editorial: The Risky Business of Fungal Infections in Patients with Cirrhosis. Am. J. Gastroenterol. 2018, 113, 564-566. [CrossRef] [PubMed]

107. Habib, S.; Yarlagadda, S.; Carreon, T.A.; Schader, L.M.; Hsu, C.-H. Fungal Infection in Acutely Decompensated Cirrhosis Patients: Value of Model for End-Stage Liver Disease Score. Gastroenterol. Res. 2020, 13, 199-207.

108. Hassan, E.A.; El-Rehim, A.S.A.; Hassany, S.M.; Ahmed, A.O.; Elsherbiny, N.M.; Mohammed, M.H. Fungal infection in patients with end-stage liver disease: Low frequency or low index of suspicion. Int. J. Infect. Dis. 2014, 23, 69-74. [CrossRef] [PubMed]

109. Pramar, Y.V.; Mandal, T.K.; Bostanian, L.A.; Nguyen, A.T.; Miller, V.; Morris, T.C.; Graves, R.A. Stability of Compounded Ursodiol Suspensions in PCCA Base, SuspendIt. Int. J. Pharm. Compd. 2019, 23, 70-76.

110. Simental-Mendía, M.; Sánchez-García, A.; Simental-Mendía, L.E. Effect of ursodeoxycholic acid on liver markers: A systematic review and meta-analysis of randomized placebo-controlled clinical trials. Br. J. Clin. Pharmacol. 2020, 86, 1476-1488. [CrossRef] 
111. Phaw, N.A.; Dyson, J.K.; Jones, D. Emerging drugs for the treatment of primary biliary cholangitis. Expert Opin. Emerg. Drugs 2020, 25, 101-112. [CrossRef]

112. Vlasova, A.N.; Kandasamy, S.; Chattha, K.S.; Rajashekara, G.; Saif, L.J. Comparison of probiotic lactobacilli and bifidobacteria effects, immune responses and rotavirus vaccines and infection in different host species. Vet. Immunol. Immunopathol. 2016, 172, 72-84. [CrossRef] [PubMed]

113. Ciorba, M.A. A gastroenterologist's guide to probiotics. Clin. Gastroenterol. Hepatol. 2012, 10, 960-968. [CrossRef] [PubMed]

114. Chu, Y.; Jiang, M.Z.; Xu, B.; Wang, W.J.; Chen, D.; Li, X.W.; Zhang, Y.J.; Liang, J. Specific changes of enteric mycobiota and virome in inflammatory bowel disease. J. Dig. Dis. 2018, 19, 2-7. [CrossRef] [PubMed]

115. Stamatiades, G.A.; Ioannou, P.; Petrikkos, G.; Tsioutis, C. Fungal infections in patients with inflammatory bowel disease: A systematic review. Mycoses 2018, 61, 366-376. [CrossRef]

116. Enaud, R.; Vandenborght, L.-E.; Coron, N.; Bazin, T.; Prevel, R.; Schaeverbeke, T.; Berger, P.; Fayon, M.; Lamireau, T.; Delhaes, L. The Mycobiome: A Neglected Component in the Microbiota-Gut-Brain Axis. Microorganisms 2018, 6, 22. [CrossRef]

117. Kantarcioglu, A.S.; Kiraz, N.; Aydin, A. Microbiota-Gut-Brain Axis: Yeast Species Isolated from Stool Samples of Children with Suspected or Diagnosed Autism Spectrum Disorders and In Vitro Susceptibility Against Nystatin and Fluconazole. Mycopathologia 2015, 181, 1-7. [CrossRef]

118. Zuo, T.; Wong, S.H.; Cheung, C.P.; Lam, K.; Lui, R.; Cheung, K.; Zhang, F.; Tang, W.; Ching, J.Y.L.; Wu, J.C.Y.; et al. Gut fungal dysbiosis correlates with reduced efficacy of fecal microbiota transplantation in Clostridium difficile infection. Nat. Commun. 2018, 9, 3663. [CrossRef]

119. Tso, G.H.W.; Reales-Calderon, J.A.; Tan, A.S.M.; Sem, X.; Le, G.T.T.; Tan, T.G.; Lai, G.C.; Srinivasan, K.G.; Yurieva, M.; Liao, W.; et al. Experimental evolution of a fungal pathogen into a gut symbiont. Science 2018, 362, 589-595. [CrossRef] 